\title{
時系列後退データを利用したサンプル時刻微分法
}

\author{
清水 浩 \\ 京都大学大学院農学研究科 606-8502 京都市左京区北白川追分町
}

\section{Numerical Differentiation Based on Sampling Time Using Time Series Sampled Data}

\author{
Hiroshi SHIMIZU \\ Graduate School of Agriculture, Kyoto University, Kyoto 606-8502, Japan
}

\begin{abstract}
Differential values such as plan growth rate are useful when developing decision-support strategies for controlling environmental conditions and plant growth. A numerical differential formula based on sampling time was developed using sampled time-series data. A smoothing filter combined with a FIR (Finite Impulse Response) filter and AR (Autoregressive) model was used to decrease the excess sensitivity of numerical differentiation. The numerical differential formula was theoretically derived from Taylor series. The proposal method was first applied to an artifical data set generated by a sine curve modified with random noise to verify performance of the proposed method. The results showed that the smoothing filter combined with the FIR filter and the AR model reduced noise such that the calculated result was similar to the original sine curve. The numerical differentiation method combined with the smoothing filter proposed in this paper was also applied to measured data of chrysanthemum stem elongation. Results showed that the proposed method acceptably calculated plant growth rate.
\end{abstract}

\section{緒言}

植物工場などにおいて環境条件をコントロールするこ とによって植物の成長を制御する場合には，制御のため の判断材料として現時点 (サンプル時刻)における植物の 成長速度, つまり成長量の時系列のデータの微分值を用 いるのが有効である ${ }^{1)}$. 時系列データ微分法としては数 值計算などで用いられる微分公式や多項式適合による微 分法などがある. 数值微分公式はノイズに非常に敏感で あり,一方多項式適合法は多項式の次数やデー夕に対す る適合範囲の選択などの決定に客観的基準が明確でなく, またデータの平滑化効果における周波数特性の操作が容 易でないなど，すぐには適用することが難しい.

そこで, 時系列データのサンプル時刻における微分值 が，過去の時系列データとの畳込みによって簡便に求め

1998 年 2 月 20 日受付

1998 年 3 月 23 日受理
ることができる微分フィルタを開発したので報告する.

\section{サンプル時刻における微分法}

まず，時系列データが $f(t)$ という関数のサンプル值 データであるとする。いま求めたいのはサンプル時刻 $t$ $=n$ でこの関数の微分值を $t<n$ のデータを用いて計算 することであるので，(1)式のような線形結合を考える.

$$
f_{\text {deriv }}(n)=\sum_{i=0}^{k} w_{i} \cdot f(n-i)
$$

続いて (1) 式を $f(n)$ およびそれらの高階導関数で表 すためにテーラー展開を行う.

時系列データのサンプリング間隔を $h$ とすると,

$$
\begin{aligned}
f(n-i)= & f(n+(-i h)) \\
= & f(n)+\frac{f^{\prime}(n)}{1 !} \cdot(-i h) \\
& +\frac{f^{\prime \prime}(n)}{2 !} \cdot(-i h)^{2}+\cdots
\end{aligned}
$$




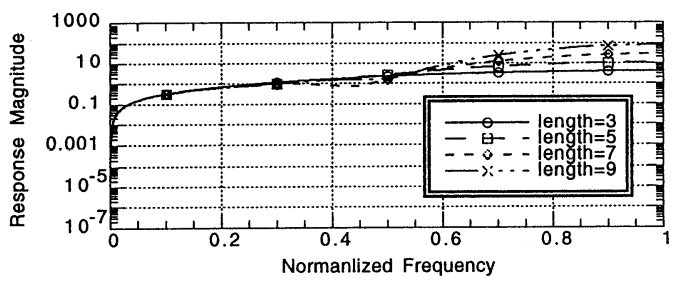

Fig. 1 Characteristics in frequency domain of differentiation filter

となる（2)式を(1)式に代入して導関数ごとに整理する と,

$$
\begin{aligned}
f_{\text {deriv }}(n)= & \left(w_{0}+w_{1}+w_{2}+w_{3}+\cdots+w_{k}\right) \cdot f(n) \\
& +\left((-1)^{1} w_{1}+(-2)^{1} w_{2}+\cdots\right. \\
& \left.+(-k)^{1} w_{k}\right) \cdot f^{\prime}(n) \frac{h}{1 !} \\
& +\left((-1)^{2} w_{1}+(-2)^{2} w_{2}+\cdots\right. \\
& \left.+(-k)^{2} w_{k}\right) \cdot f^{\prime \prime}(n) \frac{h}{2 !}
\end{aligned}
$$

となる. したがって (3) 式の右辺が $f(n)$ の 1 階導関数 となるための $w_{0}, w_{1}, \cdots, w_{k}$ の条件は, 左右辺の比較か ら

$$
W=B^{-1} \cdot A
$$

ただし，

$$
\begin{aligned}
W & =\left[\begin{array}{c}
w_{0} \\
w_{1} \\
w_{2} \\
\vdots \\
w_{k}
\end{array}\right] \\
B & =\left[\begin{array}{ccccc}
1 & (-1)^{0} & (-2)^{0} & \cdots & (-i)^{0} \\
0 & (-1)^{1} & (-2)^{1} & \cdots & (-i)^{1} \\
0 & (-1)^{2} & (-2)^{2} & \ddots & (-i)^{2} \\
\vdots & \vdots & \vdots & \vdots & \vdots
\end{array}\right] \\
A & =\left[\begin{array}{c}
0 \\
1 / h \\
0 \\
\vdots
\end{array}\right]
\end{aligned}
$$

となる.ここで $k$ をどれくらいとればよいかという問 題がある．そこで $k$ の值と周波数特性との関係を調べ たものを Fig. 1 亿示す. Fig. 1 から周波数特性への係数 $w$ の項数 $k$ の影響は少ないので計算が簡便な項数を選 択すればよい. しかしながらこの方法による微分值の計 算は雑音に弱いため, この処理を施す前に時系列デー夕 の平滑化など雑音除去操作をする必要がある.

\section{平滑化フィルタ}

上述の微分法の前処理として採用する平滑化アルゴリ ズムの条件としては，(1)サンプル時刻より過去のデー 夕を利用すること，(2)平滑化によって位相遅れが発生 しないことである。時系列データを平滑化するためのフ イルタは数多く提案されているが，(1)の条件を満たす 平滑化手法のひとつとして指数平滑化 ${ }^{2}$ が挙げられる. この平滑化法はひとつのパラメータ $\rho$ で遮断周波数を 調整するが，同時に $\rho$ によって位相特性も変化する.

Fig. 2 に示すように $\rho$ が大きくなるほど遮断周波数が低 くなるが位相遅れも大きくなる，そこで(2)の条件も満 足するため, 位相の遅れた時系列デー夕に対して, これ を逆向きにして再度処理すれば位相が元にもどることを 利用することが考えられるが，サンプル時刻より未来の データが必要となる.

このように本来サンプル時刻より過去のデータで平滑 化を行う指数平滑化法を用いても，位相のズレなどを考 慮すると未来のデー夕を用いなければならない.いずれ にしても未来のデータを予測して用いるのであれば, FIR フィルタなど設計手法が確立されている平滑化法 を用いた方が位相の遅れや遮断周波数の設計に自由度が ある。そこで平滑化法には FIR フィルタ3)，データ予測 法には AR モデル2)を採用し，これらを組合わせたもの を上述の微分法の前処理に用いた。 FIR フィルタには フーリエ級数と空関数を利用した設計法を採用し， AR モデル同定にはオフライン最小二乗法により行った. $\mathrm{AR}$ モデルによる予測精度は遅れ時間が大きくなるほど 悪くなるのでサンプル時刻より 2 サンプル未来までの予 測とし FIR フィルタのフィルタ長は 5 とした。また, AR モデル次数は AIC (赤池情報量規準)が最小になるよ うに決定した. FIR フィル夕は(5)式に示すように時系 列デー夕の線形和であり, フィル夕出力值は入力データ の中央值と対応している.

$$
f_{\text {smooth }}(n)=H \cdot C \cdot X
$$
ただし，

$$
\begin{aligned}
& H=\left[h_{1} h_{2} h_{3} h_{4} h_{5}\right] \\
& C= \\
& {\left[\begin{array}{ccccccccc}
a r_{20} & a r_{21} & a r_{22} & a r_{23} & \cdots & a r_{2 i} & \cdots & a r_{2 j} \\
a r_{10} & a r_{11} & a r_{12} & a r_{13} & \cdots & a r_{1 i} & 0 & 0 \\
1 & 0 & 0 & 0 & \cdots & 0 & \cdots & 0 \\
0 & 1 & 0 & 0 & \cdots & 0 & \cdots & 0 \\
0 & 0 & 1 & 0 & \cdots & 0 & \cdots & 0
\end{array}\right]}
\end{aligned}
$$




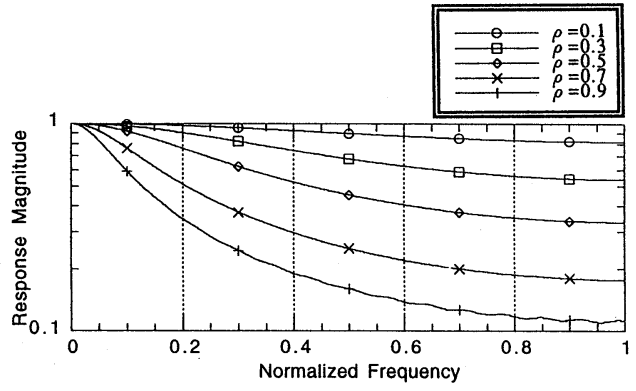

Fig. 2 Relationship between $\rho$ and characteristics in frequency domain of exponential smoothing

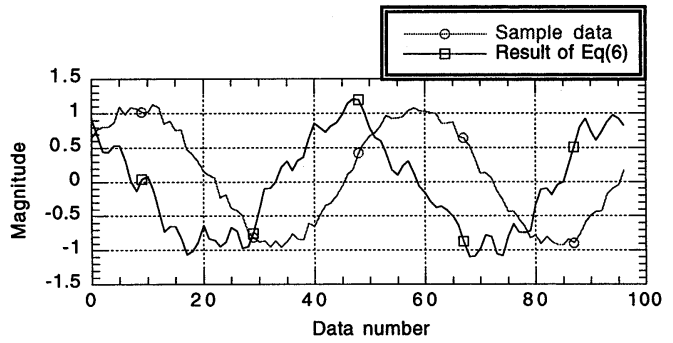

Fig. 3 Numerical differentiation by $\mathrm{Eq}(6)$

$$
X=\left[\begin{array}{c}
f(n) \\
f(n-1) \\
\vdots \\
f(n-j)
\end{array}\right]
$$

ただし， $i<j$ となる。

$H$ ベクトルの要素は FIR フィルタの係数であり, $C$ 行列の 1,2 行の要素はそれぞれ 1 段先予測および 2 段先 予測の AR モデルの係数である.一般に $i$ と $j$ は等しく ない.ここでは $i<j$ の場合を示した.

\section{時系列後退データを利用したサンプル時刻微分法}

ここまでに述べたサンプル時刻微分法とその前処理と しての平滑化フィルタを組合わせたフィルタは (6)式の ようになる.ここでは微分法の $w$ べクトルの長さは 3 としたので $B$ 行列 $3 \times 3$ である。これは Fig. 1 に示すよ うにこのべクトル長による周波数特性などへの影響がな いことからできるだけ簡便なフィルタを構築するためで ある。また， $H$ ベクトルは対象となるデータに対する 遮断周波数に依存し， $C$ 行列は対象データへの AR モ デルなので，それぞれ一般的な值というものはなく，対 象ごとに最適なものを選定しなければならない.

$$
f_{\text {deriv }}(n)=H \cdot C \cdot X \cdot B^{-1} \cdot A
$$

ただし，

$$
\begin{aligned}
& X=\left[\begin{array}{ccc}
f_{n} & f_{n-1} & f_{n-2} \\
f_{n-1} & f_{n-2} & f_{n-3} \\
\vdots & \vdots & \vdots \\
f_{n-4} & f_{n-5} & f_{n-6}
\end{array}\right] \\
& B=\left[\begin{array}{ccc}
1 & (-1)^{0} & (-2)^{0} \\
0 & (-1)^{1} & (-2)^{1} \\
0 & (-1)^{2} & (-2)^{2}
\end{array}\right] \\
& A=\left[\begin{array}{c}
0 \\
1 / h \\
0
\end{array}\right]
\end{aligned}
$$

この微分法を検証するため, サインカーブに乱数を重 畳させた疑似的な時系列デー夕を(6)式に適用した結果 を Fig. 3 に示す.この結果を得るための具体的な手続 きは, $A, B, C, H$ の行列抢よびべクトルの值を先験的 な情報により前もって求め, 時系列データの一部を $X$ ベクトルに代入し畳込みを行うだけであり，計算の手続 きは大変簡便である。ここで用いた各行列は $B, A$ は上 記の通りでありその他の行列の要素は次の通りである. $C$ ベクトルの第 1 行の次数は $\mathrm{AIC}$ が最小になる 8 次と した. 第 2 行についても同様の手続きをしたところ 8 次 となった。

$$
C=\left[\begin{array}{ccccc}
0 & 0 & 1 & -0.276 & -0.2971 \\
0 & 1 & 0 & -0.1318 & -0.1165 \\
1 & 0 & 0 & -0.006 & -0.04 \\
0 & 0 & 0 & -0.0087 & 0.017 \\
0 & 0 & 0 & 0.2074 & 0.2349 \\
0 & 0 & 0 & 0.3159 & 0.3304 \\
0 & 0 & 0 & 0.306 & 0.2921 \\
0 & 0 & 0 & 0.471 & 0.4555
\end{array}\right]^{t}
$$$$
H=\left[\begin{array}{lllll}
0.1056 & 0.2417 & 0.3054 & 0.2417 & 0.1056
\end{array}\right]^{t}
$$

図 3 において計算結果は入力データの微分值をノイズ に埋もれることなく計算しており，全体としてコサイン

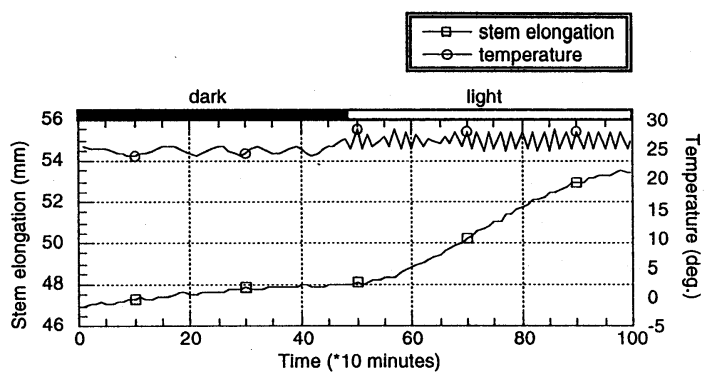

Fig. 4 Sample data of plant elongation 
カーブに近い形状になっている，ノイズに対する感度は $H$ ベクトルの値，つまり FIR フィルタの設計值に依存 しておりこの值を適宜調節することによって目的とする 誤差の範囲内に微分值を納めることが可能となる.

\section{植物成長データへの適用例}

次に実際の植物成長データを対象にサンプル時刻にお ける成長速度を求めてみる。供試の成長デー夕は画像計 測システム4)によってグロースチャンバ内で 10 分毎に 計測した Chrysanthemum paludosum の三次元伸長成長 量である.これを Fig. 4 に示す. Fig. 4 より光条件が暗 期から明期になると伸長成長が量が増大しているのが認 められる.このような時系列データに対してサンプル時 刻微分を適用した。まず先験的な情報より FIR フィル 夕の遮断周波数を決定して $H$ ベクトルの要素および $\mathrm{AR}$ モデルを決めておく.ここで用いた各行列は $C$ 行 列以外は前項と同じである。 また， $C$ 行列は次の通り である，Cべクトルの第 1 行， 2 行については前説と同 様に AIC が最小になる次数を求めたところいずれも 14 次となった.

$$
C=\left[\begin{array}{ccccc}
0 & 0 & 1 & -0.1174 & -0.1175 \\
0 & 1 & 0 & -0.0311 & -0.0086 \\
1 & 0 & 0 & -0.0086 & -0.0092 \\
0 & 0 & 0 & 0.004 & 0.0045 \\
0 & 0 & 0 & -0.0617 & -0.061 \\
0 & 0 & 0 & -0.0079 & -0.0084 \\
0 & 0 & 0 & 0.1194 & 0.1198 \\
0 & 0 & 0 & 0.0386 & 0.0398 \\
0 & 0 & 0 & 0.0453 & 0.045 \\
0 & 0 & 0 & 0.1401 & 0.1393 \\
0 & 0 & 0 & 0.0594 & 0.059 \\
0 & 0 & 0 & 0.0308 & 0.0316 \\
0 & 0 & 0 & 0.3587 & 0.3583 \\
0 & 0 & 0 & 0.432 & 0.4316
\end{array}\right]^{t}
$$

Fig. 5 に得られた結果を示す。同図には本稿で提案し た方法によって得られた結果の他に数值微分だけを施し たものを併記した. 提案した方法では光条件の変化とと もに伸長成長速度が大きくなっており，Fig. 4 の成長曲 線の傾向をマクロ的によく解釈しやすい值が得られてい る.もちろん数值微分のみの結果も原デー夕を忠実に微 分したもので数值的には間違ってはいないが，ノイズの 影響を大きく受けており植物の成長状態を判断するため
のデータとしては使いにくい，以上のように本稿で述べ た計算手法は、植物の成長データなどの時系列後退デー タからサンプル時刻の成長速度を簡便に算出するものと して有効であることが確かめられた。

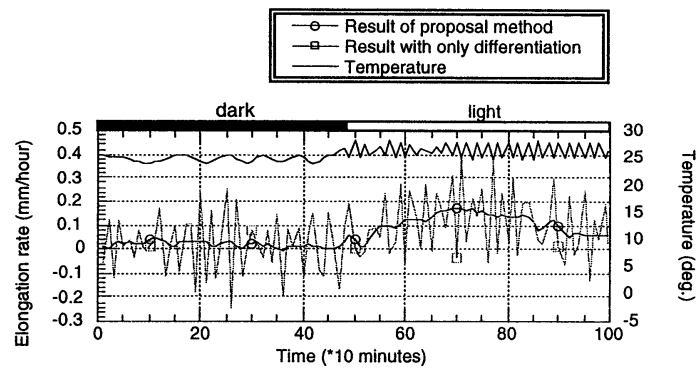

Fig. 5 Result of proposed numerical differentiation applied to a plant elongation

摘 要

植物の成長を制御するための判断基準の一つとして植 物のサンプル時刻における成長速度に着目し, ベクトル や行列と時系列後退データとの畳込みで簡便に計算する 手法を提案した。一般に用いられている関数を近似する 方法では関数の決定方法などに客観的基準がなく周波数 特性などの操作も容易ではなく,さらに(6)式のように 時系列データとの畳込みという非常に簡潔な手続きだけ で結果を得ることは難しい. 一方，本稿で提案した手法 は生育環境制御システムの一部としても組込める可能性 があると考える。

\section{引用文献}

1) 清水 浩：ローパスフィル夕遮断周波数の調整に よる植物生長データのノイズ除去法, 植物工場学 会誌，8(4)：237-243(1996)

2）鈴木義一郎：デー夕解析術, 実教出版, pp. 110129(1989)

3） 三谷政昭：デジタルフィルタデザイン，昭晃堂, pp. 55-101 (1991)

4) H. Shimizu and R. D. Heins : Computer-Vision -Based system for plant growth analysis, Trans. of the ASAE, 38(3) : 959-964 (1995) 